\title{
Chemical composition, larvicidal and cytotoxic activity of Annona salzmannii (Annonaceae) seed oil
}

\author{
Jane Cristina Lara Ribeiro ${ }^{1}$, Estevan Bruginski ${ }^{1}$, Tatiana Zuccolotto ${ }^{1}$, \\ Alan Diego da Conceição Santos ${ }^{2,5}$, Larissa Mendes Bomfim ${ }^{3}$, \\ Suellen Laila Andrade Rocha ${ }^{3}$, Andersson Barison ${ }^{2}$, Guilherme Sassaki², \\ Sócrates Cabral de Holanda Cavalcanti ${ }^{4}$, Emmanoel Vilaça Costa ${ }^{5}$, \\ Milena Botelho Pereira Soares ${ }^{3}$, Daniel Pereira Bezerra ${ }^{3}$, \\ Francinete Ramos Campos ${ }^{\oplus \text {,* }}$
}

${ }^{1}$ Department of Pharmacy, Federal University of Paraná, Curitiba, Paraná, Brazil, ${ }^{2} N M R$ Center, Federal University of Paraná, Curitiba, Paraná, Brazil, ${ }^{3}$ Gonçalo Moniz Research Center, Oswaldo Cruz Foundation, Salvador, Bahia, Brazil, ${ }^{4}$ Department of Pharmacy, Federal University of Sergipe, Brazil, ${ }^{5}$ Department of Chemistry, Federal University of Amazonas, Manaus, Amazonas, Brazil

\begin{abstract}
The seed oil of Annona salzmannii A. DC. was analyzed by GC-MS and ${ }^{1} \mathrm{H}$ qNMR, revealing a mixture of unsaturated $(80.5 \%)$ and saturated $(18.7 \%)$ fatty acids. Linoleic $(45.3 \%)$ and oleic $(33.5 \%)$ acid were the major unsaturated fatty acids identified, while palmitic acid (14.3\%) was the major saturated fatty acid. The larvicidal effects of $A$. salzmannii seed oil were evaluated against third-instar larvae of Aedes aegypti (Linn.). The oil exhibited moderate larvicidal activity, with a $\mathrm{LC}_{50}$ of $569.77 \mathrm{ppm}(95 \% \mathrm{CI}=408.11$ to $825.88 \mathrm{ppm})$. However, when the cytotoxic effects of the oil were evaluated, no expressive antiproliferative effects were observed in tumor cell lines B16-F10 (mouse melanoma), HepG2 (human hepatocellular carcinoma), K562 (human chronic myelocytic leukemia), HL-60 (human promyelocytic leukemia), and non-tumor cell line PBMC (peripheral blood mononuclear cells), with $\mathrm{IC}_{50}$ values $>50 \mu \mathrm{g} \cdot \mathrm{mL}^{-1}$. This is the first study to evaluate the chemical composition, larvicidal and cytotoxic activity of $A$. salzmannii seed oil.
\end{abstract}

Keywords: Annona salzmannii. Annonaceae. Larvicidal activity. Cytotoxic activity. Seed oil.

\section{INTRODUCTION}

The family Annonaceae is extremely diverse, having a pantropical distribution comprised of approximately 2500 species distributed throughout 135 genera. In the neotropics, the family is represented by 40 genera composed of approximately 900 species distributed across the Amazonia and Guianas (Chatrou, Rainer, Maas, 2004). Species of the family Annonaceae are extremely common in Brazil, mainly in Bahia, Minas Gerais, São Paulo, Pernambuco, and Paraíba (Sobrinho,

*Correspondence: F. R. Campos. Departamento de Farmácia. Universidade Federal do Paraná. Avenida Prefeito Lothário Meissner, 632. Curitiba, 80210-170, PR, Brazil. Phone: +55 41 3360-4162. Fax: +55 41 3360-4106. E-mail: francampos@ufpr.br
2010; São José et al., 2014). Due to its economic importance, the genus Annona is significant, with emphasis being placed on species with market potential, including $A$. muricata L. ("graviola"), A. squamosa L. ("pinha" or "fruta-do-conde"), and A. atemoya (a hybrid of $A$. squamosa and $A$. cherimola) (Pereira et al., 2011; São José et al., 2014). These species produce exotic and savory fruits having nutritional value and bioactive properties, which in turn bring health benefits (Jiang, Bryce, Horrobin, 1998; Luzia, Jorge, 2012; São José et al., 2014). These characteristics have led to great acceptance of these fruits in the world market. Additionally, some species have been reported in the literature as having pharmacological importance in the production of phytochemical (São José et al., 2014) and 
insecticidal properties for the control of Aedes aegypti (Ae. aegypti) (Linn.) (Diptera: Culicidae) (Dill, Pereira, Costa 2012; Costa et al., 2013c; Grzybowski et al., 2013).

Zika, Dengue, and Chikungunya are diseases transmitted to humans by the mosquito Ae. aegypti L. After viral infection, these diseases cause flu-like symptoms that may progress into more serious conditions (WHO, 2015). The Zika virus has caught the attention of world authorities as it can cause microcephaly up to eight months after viral clearance and be sexually transmitted. Although the disease itself is not vectored in non-tropical regions, it has become a global concern (Rasmussen, 2016) due to the virus being commonly found in locations having high tourist traffic. Since there are no specific treatments or vaccines for Zika and Chikungunya, the only method for controlling and/or preventing viral transmission is to control the mosquito vector through environmental management and chemical methods.

Larvicides target larvae in breeding sites before they grow into unmanageable adult targets. Larviciding is considered the most appropriate method for Ae. aegypti L. control due to its method of action occurring during the early stages of larval development in a contained environment. Although there are several larvicides available for mosquito control, only six products for Ae. aegypti L. control in drinking water have been approved by the WHO: organophosphate temephos, Bacillus thuringiensis israelensis (BTI) protein, chitin synthesis inhibitors diflubenzuron and novaluron, and juvenile hormone analogs methoprene and pyriproxyfen (WHO, 2006). The application of larvicides and insecticides, such as malathion, as space sprays have resulted in mosquito resistance in subtropical and tropical regions of the world. Additionally, non-selective chemical usage has caused damage to non-target organisms, other than the transmitting vector, and the environment (Songa, 2016). As a result, pesticide resistance has persuaded researchers to find new methods to control Ae. aegypti L. proliferation involving syntheses of hit molecules and formulation, implementation, and efficacy evaluations of new plant extract-based products in the field.

Seeds of Annonaceae are an interesting source of vegetable oils that are currently discarded. These oils are mostly composed of essential fatty acids (EFAs), such as oleic acid (OA), stearic acid (SA), and linoleic acid (LA). These EFAs cannot be biosynthesized by humans and then must be obtained from the diet. Moreover, several studies have reported the cytotoxic effects of EFAs on different types of tumor cell lines (Meterissian et al., 1995; Du Toit, Van Aswegen, Du Plessis, 1996; Comba et al., 2010; Moon,
Batirel, Mantzoros, 2014; Soto-Gusman et al., 2013; Zajdel, Wilczock, Tarkowski, 2015). Therefore, the search for new sources of EFAs is essential, and the seeds of edible fruits are an interesting option for consideration in this context as well as serving as potential sources of fatty oils for production of edible oils and condiments (Ferreira et al., 2006; Silva et al., 2015; Issaoui, Delgado, 2019; Ramadan, 2019). Additionally, species of the family Annonaceae have been shown to be promising sources of alternative fuels for conventional diesel engines and biodiesel production (Reyes-Trejo et al., 2014; Senthil, Silambarasan, 2015).

Annona salzmannii A. DC. (popularly known as "araticum-da-mata" or "araticum-apé") is a 6-20 m-tall tree found in northeast Brazil, mainly in Pernambuco, Paraíba, and Bahia (Pereira et al., 2011; São José et al., 2014). Their leaves, bark, roots, and seeds of A. salzmannii are used in traditional medicine to treat human illnesses, such as diabetes, tumors, ulcers, and inflammation (Corrêa, 1984). Previous studies on the chemical composition, antioxidant, antitumor, trypanocidal, antimicrobial, and larvicidal activity of essential oils from the leaves (Costa et al., 2011; Costa et al., 2013a), antitumor activity of extracts from the leaves and bark (Ribeiro et al., 2012), and antimicrobial and antioxidant activity of alkaloids from the bark (Paulo et al., 1992; Costa et al., 2013b) regarding $A$. salzmannii can be found in the literature.

The present study aimed to evaluate the chemical composition of $A$. salzmannii seed oil by means of gas chromatography-mass spectrometry (GC-MS) and ${ }^{1} \mathrm{H}$ quantitative nuclear magnetic resonance (qNMR) spectroscopy and investigate its larvicidal activity against Ae. aegypti L. larvae, as well. Furthermore, cytotoxic effects were investigated against tumor cell lines B16-F10 (mouse melanoma), HepG2 (human hepatocellular carcinoma), K562 (human chronic myelocytic leukemia), HL-60 (human promyelocytic leukemia), and non-tumor cell line PBMC (peripheral blood mononuclear cells) in order to improve the chemical and biological knowledge of the Brazilian Annonaceae species.

\section{MATERIAL AND METHODS}

\section{Chemicals and Standards}

Methanol and deuterated chloroform were obtained from Sigma-Aldrich (St. Louis, MO). A reference standard mix of fatty acid methyl esters (FAMEs) in methylene chloride (grain fatty acid methyl ester mix 99-100\%, \#47801) was purchased from Supelco (Bellefonte, PA). All 
other chemicals and solvents were of analytical grade and obtained from Vetec Química Fina Ltda. (Duque de Caxias, RJ, Brazil) or Tedia Brazil (Rio de Janeiro, RJ, Brazil).

\section{Plant material}

Fruits of Annona salzmannii A. DC. were collected from Mata do Crasto, Santa Luzia do Itanhy [coordinates: $11^{\circ} 24^{\prime} 24^{\prime \prime}$ S, 37 $25^{\prime} 86^{\prime \prime}$ 'W], Sergipe, Brazil in November 2012 (SISGEN \#ACAAA36). The material was identified by Prof. Dr. Ana Paula Nascimento Prata, a taxonomist in the Department of Biology at the Federal University of Sergipe. A voucher specimen (\#25603) was deposited in the Herbarium of the Federal University of Sergipe (ASE/ UFS), Sergipe, Brazil. This work was performed according to special authorization for access to genetic resources in Brazil \#010240/2013-6, issued by CNPq/MCTI.

\section{Seed oil extraction}

Seeds of $A$. salzmannii were removed from the mature fruits, washed with water to remove pulp, and dried in a circulating air oven at $45{ }^{\circ} \mathrm{C}$ for five days. They were then milled using a cutting mill. The seeds $(752.0 \mathrm{~g})$ were submitted to exhaustive extraction with $n$-hexane (four times, one liter each) for $24 \mathrm{~h}$ at room temperature $\left(\approx 24^{\circ} \mathrm{C}\right)$. The resultant crude extract was submitted to solvent removal with aid of a low-pressure evaporator $\left(40-50{ }^{\circ} \mathrm{C}\right)$ and then dried under a continuous stream of $\mathrm{N}_{2}$ gas.

\section{GC-MS and ${ }^{1} \mathrm{H}$ qNMR seed oil analyses}

Aliquots of the seed oil $(100 \mu \mathrm{L})$ were dissolved in $\mathrm{CHCl}_{3}-\mathrm{MeOH}(1: 1 v / v)$ solution and dried under a gentle stream of $\mathrm{N}_{2}$ gas. Methanolysis was then carried out with methanol-methanolic $\mathrm{HCl}\left(1 \mathrm{~mol} \cdot \mathrm{L}^{-1}\right)$ at $100{ }^{\circ} \mathrm{C}$ for $2 \mathrm{~h}$ to obtain FAMEs. The resulting FAMEs were extracted by partition between $n$-hexane $(1 \mathrm{~mL})$ and distilled water $(0.5 \mathrm{~mL})$. The organic phase (top phase) was collected and evaporated under a stream of $\mathrm{N}_{2}$. The derivatives were then directly injected into the GC-MS chromatograph. The analyses were carried out on a Varian 3800 GC system with a Saturn 2000 RMS detector (Agilent Technologies, Santa Clara, CA) equipped with a $30 \mathrm{~m} \times$ $0.25 \mathrm{~mm}$ i.d. low-bleed/MS DB-225 capillary column. The temperature ramp used for the FAME analyses was: injector $250{ }^{\circ} \mathrm{C}$; initial oven $50{ }^{\circ} \mathrm{C}$, hold for $2 \mathrm{~min}$, then heat to $210^{\circ} \mathrm{C}\left(40{ }^{\circ} \mathrm{C}\right.$ per min, then hold for 45 min). Electron ionization (EI) spectra were obtained at
$70 \mathrm{eV}$ and $200{ }^{\circ} \mathrm{C}$. The injection volume was $5 \mu \mathrm{L}$ at $\mathrm{mg} / 200 \mu \mathrm{L}$ with a split ratio of 1:5. Post-run analyses were performed on a Saturn Workstation 5.1. software (Sassaki et al., 2008). FAMEs were identified through comparison with retention times of standards (National Institute of Standards and Technology, 1992; National Institute of Standards and Technology, 1998).

Quantitative ${ }^{1} \mathrm{H}$ NMR (qNMR) spectra were acquired in $\mathrm{CDCl}_{3}$ at $303 \mathrm{~K}$ on a Bruker AVANCE III $600 \mathrm{NMR}$ spectrometer. Relative quantification of the fatty acids was determined from the ${ }^{1} \mathrm{H}$ qNMR spectra according to Barison et al. (2010).

\section{Larvicidal assay}

The larvicidal assay was performed using Ae. aegypti L. third-instar larvae (Rockefeller strain) (Santos et al., 2010). Concentration ranges were determined based on a previous concentration-response curve of 20 larvae. A 20,000 ppm stock solution was prepared using the seed oil $\left(20 \mathrm{mg} \cdot \mathrm{mL}^{-1}\right)$, Tween $80(10 \% \mathrm{v} / \mathrm{v})$, dimethyl sulfoxide (DMSO) $(30 \% v / v)$, and dechlorinated water $(60 \% v / v)$. The stock solution was used to make $20 \mathrm{~mL}$ water solutions ranging from 10 to $1000 \mathrm{ppm}$. Twenty larvae were collected with a Pasteur pipette and placed in a $25 \mathrm{~mL}$ graduated cylinder. Dechlorinated water was added to a volume of $20 \mathrm{~mL}$, and the solution was then transferred to disposable cups containing variable volumes of stock solution. A mortality count was conducted after $24 \mathrm{~h}$ of treatment. Controls were prepared at the highest concentration used in the larvicidal assay [Tween $80(0.75 \%)$ and DMSO (2.25\%) in dechlorinated water]. Each solution concentration and control were performed in triplicate. As a positive control, commonly used organophosphate insecticide temephos was used at concentrations of $0.015-0.135 \mathrm{ppm}$. Probit analysis (Finney, Stevens, 1948) was conducted on the mortality data, collected after $24 \mathrm{~h}$ exposure to different concentrations of testing solutions, to establish lethal concentration for $50 \%$ mortality $\left(\mathrm{LC}_{50}\right)$ and $95 \%$ confidence interval (CI) values for each sample and temephos. For the cases where deaths occurred during the control experiment, mortality data were corrected using Abbott's formula: $(\%$ Death $=[1$ (test/control $)] \times 100)$.

\section{Cell lines}

Tumor cell lines B16-F10 (mouse melanoma) and HepG2 (human hepatocellular carcinoma), K562 (human chronic myelocytic leukemia) and HL-60 
(human promyelocytic leukemia), and non-tumor cell line PBMCs (peripheral blood mononuclear cells) were donated by Hospital A.C. Camargo, São Paulo, SP, Brazil. Cells were maintained in RPMI-1640 medium (GibcoBRL, Gaithersburg, MD) supplemented with $10 \%$ fetal bovine serum (Cultilab, Campinas, SP, Brazil), $2 \mathrm{mM}$ glutamine, and $50 \mathrm{mg} \cdot \mathrm{mL}^{-1}$ gentamicin. Adherent cells were harvested through treatment with $0.25 \%$ trypsinEDTA solution (Gibco-BRL, Gaithersburg, MD). All cell lines were cultivated in cell culture flasks at $37^{\circ} \mathrm{C}$ under $5 \% \mathrm{CO}_{2}$ and were subcultured every 3-4 days to maintain exponential growth. Cytotoxicity experiments were conducted using cells in the exponential growth phase. All cell lines were tested for mycoplasma using a LookOut mycoplasma qPCR detection kit (Sigma-Aldrich Corp., St. Louis, MO) and were free of contamination.

Human lymphocyte cells were obtained by primary culture. Heparinized blood samples (from healthy, nonsmoking donors who had not taken any drugs for at least 15 days before sampling) were collected and peripheral blood mononuclear cells (PBMC) were isolated using a standard Ficoll density gradient protocol (Ficoll-Paque PLUS; GE Healthcare Bio-Sciences AB, Björkgatan, Upsalla, Sweden). The PBMC were washed and resuspended at a concentration of $0.3 \times 10^{6}$ cells $/ \mathrm{mL}$ in RPMI-1640 medium supplemented with $20 \%$ fetal bovine serum, $2 \mathrm{mM}$ glutamine, and $50 \mu \mathrm{g} \cdot \mathrm{mL}^{-1}$ gentamicin at $37^{\circ} \mathrm{C}$ under $5 \% \mathrm{CO}_{2}$. Additionally, concanavalin A (ConA; Sigma-Aldrich Corp., St Louis, MO) was used as a mitogen to trigger cell division of T-lymphocytes. ConA $\left(10 \mu \mathrm{g} \cdot \mathrm{mL}^{-1}\right)$ was added at the start of the culture, and the cells were treated with seed oil after $24 \mathrm{~h}$.

\section{Cytotoxicity assay}

Cell viability was quantified by alamarBlue assay (Ahmed, Gogal, Walsh, 1994). For all experiments, cells were cultivated in 96 -well plates $\left(0.7 \times 10^{5}\right.$ cells $/ \mathrm{mL}$ for adherent or $0.3 \times 10^{6}$ cells $/ \mathrm{mL}$ for suspended cells in 100 $\mathrm{mL}$ of medium). After $24 \mathrm{~h}$, seed oil $\left(0.19-50 \mu \mathrm{g} \cdot \mathrm{mL}^{-1}\right)$ dissolved in DMSO (LGC Biotechnology, São Paulo, SP, Brazil) was added to each well for incubation for $72 \mathrm{~h}$. Doxorubicin (doxorubicin hydrochloride, purity 99.0\%; Sigma-Aldrich Corp., St. Louis, MO) was used as a positive control. The negative control was composed of the solution $(0.5 \%$ DMSO) used for the sample dilutions. Four hours ( $24 \mathrm{~h}$ for the PBMC) before ending incubation, $20 \mathrm{~mL}$ of alamarBlue stock solution $(0.312$ $\mathrm{mg} \cdot \mathrm{mL}^{-1}$ ) (resazurin; Sigma-Aldrich Corp., St. Louis,
MO) was added to each well. Absorbance measurements were obtained on a SpectraMax 190 microplate reader (Molecular Devices, San Jose, CA), and drug effects were quantified as a percentage of the control absorbance at 570 and $600 \mathrm{~nm}$. Data are presented as the mean \pm standard deviation (SD) of two independent experiments performed in triplicate. All statistical analyses were carried out on a GraphPad Prism v6 software (GraphPad Software Inc.).

\section{RESULTS AND DISCUSSION}

The extraction of $A$. salzmannii seed resulted in a yellow crude oil which comprises $25.2 \%$ of that of the dry weight plant material. Quantitative information on the chemical components of the seed oil was assessed though GC-MS and ${ }^{1} \mathrm{H}$ qNMR. Additionally, the larvicidal and cytotoxic effects of the seed oil were investigated.

GC-MS analyses of the seed oil revealed a fraction rich in methyl esters, containing a high percentage of unsaturated fatty acids (80.5\%), including linoleic (LA) and oleic (OA) acids (45.3\% and $33.5 \%$, respectively), and a low concentration of palmitoleic acid (1.7\%). Regarding saturated fatty acids (18.7\%), palmitic acid $(14.3 \%)$ was the most abundant, followed by stearic acid (4.4\%), while linolenic and myristic acids were not detected (Table I).

The ${ }^{1} \mathrm{H}$ qNMR spectra from $A$. salzmannii seed oil revealed the presence of signals related to triacylglycerols containing OA, LA moieties, and saturated fatty acids (Figure 1). Therefore, the relative amounts of each fatty acid esterified to a glycerol moiety were determined, revealing that the oil is composed of OA (35.1\%), LA (49.3\%), and saturated fatty acids (13.5\%).

The findings observed in this study are in accordance to those for other Annona species, including A. cornifolia (Lima et al., 2011), A. squamosa (Ansari, Afaque, Ahmad, 1985), A. crassiflora (Luzia, Jorge, 2013), A. diversifolia (Reyes-Trejo et al., 2014), and A. muricate (Castro et al., 1984), where the unsaturated fatty acids content was higher than that of saturated fatty acids, ranging from 71.4 to $78.4 \%$. In previous studies, the saturated fatty acid contents varied from 21.6 to $33.3 \%$. Comparatively, the seeds of $A$. salzmannii appear to have a higher amount of unsaturated fatty acids and lower amount of saturated fatty acids than those of other Annona species. Linolenic acid, for example, is either not present or present in low concentrations $(<1 \%$ of the total fatty acid content) in other species (Barison et al., 2010). 
TABLE I - Fatty acids analysis by GC-MS of Annona salzmannii seed oil

\begin{tabular}{cccc}
\hline Peak & Name $^{\mathbf{a}}$ & ${\text { Rt }(\mathbf{m i n})^{\mathbf{b}}}^{\mathbf{b}}$ & EI-MS $(\mathbf{m} / \mathbf{z})^{\mathbf{c}}$ \\
\hline 1 & Palmitic acid (16:0) & 6.454 & $55,73.9,101,143,227.1,270,271.1$ \\
\hline 2 & Palmitoleic acid (16:1) & 6.565 & $55,69,83,97$ \\
\hline 3 & Stearic acid (18:0) & 7.777 & $55,73.9,75,87,101,143.1,199.1,255.2,298$ \\
\hline 4 & Oleic acid (18:1n-6) & 7.922 & $55,67.1,81,82,97,123,264,296.8$ \\
\hline 5 & Linoleic acid (18:2) & 8.252 & $67.1,81,95.1,108.9$ \\
\hline
\end{tabular}

${ }^{a}$ Name of the fatty acid, ${ }^{b}$ Retention time, ${ }^{c}$ Eletron Ionization-Mass Spectrometry

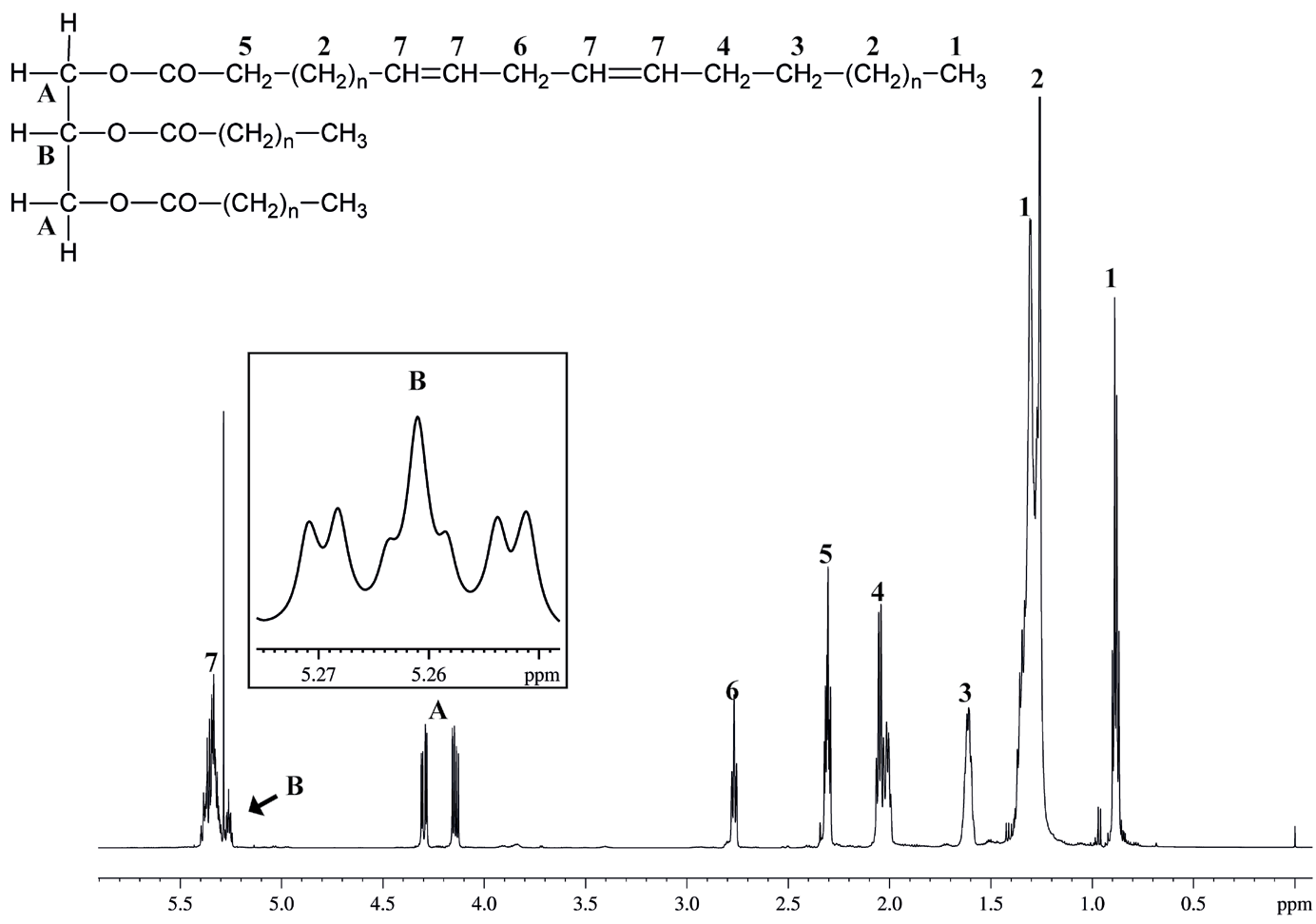

FIGURE 1 - ${ }^{1} \mathrm{H}$ qNMR spectrum of Annona salzmannii seed oil.

Table II shows the percent mortality of $A$. salzmannii seed oil against third-instar Ae. aegypti L. At the highest concentration, $1500 \mathrm{ppm}$, the seed oil caused 76.6\% mortality, while lower concentrations resulted in lower mortality. A. salzmannii seed oil exhibited moderate larvicidal activity $\left(\mathrm{LC}_{50}=569.7 \mathrm{ppm}, \mathrm{CI}=408.1\right.$ to 825.8 ppm) against Ae. aegypti, while the positive control, a
WHO-approved larvicide, temephos, exhibited a $\mathrm{LC}_{50}$ $=0.003 \mathrm{ppm}$ ( 0.0030 to $0.0039 \mathrm{ppm})$. No mortality was observed for the negative controls.

In the literature, there are few reports of insecticide assays using Annona seeds. The larvicidal effects of Annona muricata seed-ethanol extract-water suspension against fourth-instar Ae. aegypti L. larvae have been 
shown to produce $100 \%$ mortality at $0.5 \mathrm{mg} \cdot \mathrm{mL}^{-1}$ after $24 \mathrm{~h}$ exposure (Bobadilla, Sisnigas, Zavaleta, 2005). However, no difference in the mortality rate was observed between acetogenins polar (ethanol) and non-polar (petroleum ether) extracts of $A$. muricata seeds evaluated against third- and fourth-instar larvae, showing $100 \%$ mortality at $0.18 \mathrm{mg} \cdot \mathrm{mL}^{-1}$ for both (Morales, Gonzáles, Aragón, 2004). In addition, bioassays of methanol and hexane extracts of $A$. coriacea seeds against Ae. aegypti L. larvae at concentrations $<0.1 \mathrm{mg} \cdot \mathrm{mL}^{-1}$ resulted in $100 \%$ mortality at all concentrations tested $\left(\mathrm{LC}_{50}=0.007\right.$ $\left.\mathrm{mg} \cdot \mathrm{mL}^{-1}\right)$ (Costa et al., 2013c).

TABLE II - Percentage mortality of Aedes aegypti mosquito larvae in the control and experimental group after exposition to Annona salzmannii seed oil for $24 \mathrm{~h}$

\begin{tabular}{cc}
\hline Concentration (ppm) & Average \% Mortality \\
\hline Annona salzmannii seed oil & \\
10 & 6.6 \\
100 & 13.3 \\
450 & 35.0 \\
1000 & 63.3 \\
1500 & 76.6 \\
\hline
\end{tabular}

\section{Positive control (temephos)}

$\begin{array}{lc}0.001 & 3.3 \\ 0.003 & 33.3 \\ 0.005 & 75.0 \\ 0.007 & 88.3 \\ 0.011 & 98.3\end{array}$

Negative control

0

Literature results have also shown differences in extracts and fractions of $A$. crassiflora seeds against third-instar Ae. aegypti L. larvae. Crude extracts of $A$. crassiflora showed higher mortality rates than those of the fractions. Extracts of hexane $\left(\mathrm{LC}_{50}=0.507 \mathrm{mg} \cdot \mathrm{mL}^{-1}\right)$ and dichloromethane $\left(\mathrm{LC}_{50}=0.185 \mathrm{mg} \cdot \mathrm{mL}^{-1}\right)$, as well as hexane fractions $\left(\mathrm{LC}_{50}=0.433 \mathrm{mg} \cdot \mathrm{mL}^{-1}\right)$, showed mortality rates $>90 \%$ at $1.0 \mathrm{mg} \cdot \mathrm{mL}^{-1}$ (Costa et al., 2013c).

Therefore, it has been demonstrated that the bioactivity of species of the family Annonaceae on Ae. aegypti L. larvae can vary significantly depending on species, as well as the extraction solvents and concentrations used.

To investigate mammalian toxicity, the cytotoxic effects of A. salzmannii seed oil were evaluated against tumor cell lines B16-F10, HepG2, K562, HL-60, and non-tumor cell line PBMC. The cytotoxicity assay of the seed oil from $A$. salzmannii was initially performed at a concentration of $50 \mu \mathrm{g} \cdot \mathrm{mL}^{-1}$ against BF6-F10 and HepG2 tumor cell lines. The seed oil was active once it caused $84.19 \pm 8.18$ and $72.96 \pm 12.65$ cell growth inhibition of BF6-F10 and HepG2, respectively. Furthermore, the oil was tested in the B16-F10, HepG2, K562, and HL-60 tumor cell lines and PBMC normal cell line to determine $50 \%$ inhibitory concentrations $\left(\mathrm{IC}_{50}\right)$.

According to the criteria adopted by the American National Cancer Institute and our cytotoxic screening assay, a crude extract oil showing an $\mathrm{IC}_{50}$ value $<30$ $\mu \mathrm{g} \cdot \mathrm{mL}^{-1}$ in tumor cell lines is considered promising for anticancer drug development (Suffness, Pezzuto, 1990). The oil from $A$. salzmannii seeds did not show any expressive antiproliferative effects, with $\mathrm{IC}_{50}$ values $>50$ $\mu \mathrm{g} \cdot \mathrm{mL}^{-1}$ in the tumor cell lines tested. Although the seed oil has a high content of unsaturated fatty acids and a well-known antineoplastic activity (Fauser et al., 2011), it did not show cytotoxic effects against the tumor and non-tumor cell lines.

Different cytotoxic effects have been reported for some species of Annona. FAMEs from the seed oil of $A$. cornifolia have shown interesting cytostatic and cytocidal effects against some tumor cell lines (Lima et al., 2012). This oil also had a high percentage of unsaturated (71.4\%) versus saturated (22.7\%) fatty acids (Lima et al., 2011). The seed oil of $A$. squamosa has been shown to suppress H22 solid tumor development, which might be attributed to the presence of unsaturated fatty acids and acetogenins. Additionally, this oil showed selective cytotoxic activity against HepG2 cell lines (Chen et al., 2016).

In the literature, the cytotoxic effects of fatty acids have been individually evaluated in different tumor cell lines with differing results (Meterissian et al., 1995; Du Toit, Aswegen, Du Plessis, 1996; Soto-Guzman et al., 2013; Moon, Batriel, Mantzoros, 2014; Wang et al., 2014).

In this context, when evaluating the effects of fatty acids on tumor cell lines, the fatty acid type, degree of 
saturation/desaturation, method of delivery to cancer cells or host, and tumor/cell type must be considered (Jiang, Brice, Horrobin, 1998). Another consideration is that the chemical compositions of seed oils may contain other metabolites besides triacylglycerides, such as acetogenins, which are highly cytotoxic.

This report presents the first study on the chemical composition, larvicidal effects, and cytotoxicity of $A$. salzmannii seed oil. The oil was found to have a high percentage of unsaturated $(80.5 \%)$ and saturated $(18.7 \%)$ fatty acids (i.e. fatty acid esterified to a glycerol moiety), which make it an interesting source of EFAs. Furthermore, the oil exhibited moderate larvicidal toxicity against $A e$. aegypti L. larvae and did not show cytotoxic effects in tumor and non-tumor mammalian cell lines.

\section{ACKNOWLEDGEMENTS}

The authors are grateful to the Brazilian agencies CAPES, CNPq, FINEP, FAPITEC/SE, FAPESB, Fundação Araucária for their financial support and fellowships. The authors also thank Prof. Dr. Ana Paula Nascimento Prata, a taxonomist in the Department of Biology at the Federal University of Sergipe, for identification of the botanical material. Additional thanks to Dr. Vinci Hung for critical reading and revision of this manuscript.

\section{REFERENCES}

Ahmed SA, Gogal RM, Walsh JE. A new rapid and simple non-radioactive assay to monitor and determine the proliferation of lymphocytes: an alternative to $\left.{ }^{3} \mathrm{H}\right]$ thymidine incorporation assay. J Immunol Methods. 1994;170(2):211-24.

Ansari MH, Afaque S, Ahmad M. Isoricinoleic acid in Annona squamosa seed oil. J Am Oil Chem Soc. 1985;62(10):15141514.

Barison A, Silva CWP, Campos FR, Simonelli F, Lenz CA, Ferreira AG. A simple methodology for the determination of fatty acid composition in edible oils through ${ }^{1} \mathrm{H}$ NMR spectroscopy. Magn Reson Chem. 2010;48(8):642-650.

Bobadilla M, Sisniegas M, Zavaleta G. Evaluacíon larvicida de suspensiones acuosas de Annona muricata Linnaeus «guanábana» sobre Aedes aegypti Linnaeus (Diptera, Culicidae). Rev Peru Biol. 2005;12(1):145-152.

Castro FA de, Maia GA, Flavio L, Holanda F, Guedes ZB, Moura DEA. Características Físicas e Químicas da Graviola. Pesq Agropec Bras. 1984;19(3):361-365.
Chatrou LW, Rainer H, Maas PJM. Annonaceae. In: Smith N, Mori SA, Henderson, A, Stevenson DW, Heald SV. (eds.) Flowering plants of the Neotropics. Princeton University Press and The New York Botanical Garden, Princeton; 2004. p. 18-20.

Chen Y, Chen Y, Shi Y, Ma C, Wang X, Li Y, et al. Antitumor activity of Annona squamosa seed oil. J Ethnopharmacol. 2016;193:362-367.

Comba A, Maestri DM, Berra MA, Garcia C, Das UN, Eynard AR, et al. Effect of $\omega-3$ and $\omega-9$ fatty acid rich oils on lipoxygenases and cyclooxygenases enzymes and on the growth of a mammary adenocarcinoma model. Lipids Health Dis. 2010;9(1):1-11.

Corrêa MP. Dicionário de plantas úteis do Brasil e de plantas exóticas cultivadas. Rio de Janeiro: Ministério da Agricultura, Instituto Brasileiro de Desenvolvimento Florestal; 1984. p. 151-162.

Costa EV, Dutra LM, Jesus HCR, Nogueira PCL, Moraes VRS, Salvador MJ, Cavalcanti SCH, Santos RC, Prata APN. Chemical Composition and Antioxidant, Antimicrobial, and Larvicidal Activities of the essential Oils of Annona salzmannii and A. pickelii (Annonaceae). Nat Prod Comm. 2011;6(6):907-912.

Costa EV, Dutra LM, Salvador MJ, Ribeiro LH, Gadelha FR, Carvalho JE. Chemical composition of the essential oils of Annona pickelii and Annona salzmannii (Annonaceae), and their antitumour and trypanocidal activities. Nat Prod Res. 2013a;27(11):997-1001.

Costa EV, Cruz PEO da, Lourenço CC, Moraes VRS, Nogueira PCL, Salvador MJ. Antioxidant and antimicrobial activities of aporphinoids and other alkaloids from the bark of Annona salzmannii A. DC. (Annonaceae). Nat Prod Res. 2013b;27(11):1002-1006.

Costa MS, Pereira MJB, Oliveira SS, Souza PT, Dall'oglio EL, Alves TC. Anonaceas provocam mortalidade em larvas de Aedes aegypti (Linnaeus, 1762) (Diptera: Culicidae). Rev Bras de Bioci. 2013c;11(2):184-190.

Dill EM, Pereira MJB, Costa MS. Efeito residual do extrato de Annona coriacea sobre Aedes aegypti. Arq Inst Biol. 2012;79(4):595-601.

Du Toit PJ, Van Aswegen CH, Du Plessis DJ. The effect of essential fatty acids on growth and urokinase-type plasminogen activator production in human prostate DU-145 cells, Prostaglandins Leukot. Essent Fat. Acids. 1996;55(3):173-177.

Fauser JK, Prisciandaro LD, Cummins AG, Howarth GS. Fatty acids as potential adjunctive colorectal chemotherapeutic agents. Cancer Biol Ther. 2011;11(8):724-731. 
Ferreira FR, Vieira RF, Costa TSA, Silva DB, Sano SM. Frutas nativas da região Centro-Oeste do Brasil. 1a ed. Brasília: Embrapa Recursos Genéticos e Biotecnologia; 2006. 320 p.

Finney DJ, Stevens WL. A Table for the Calculation of Working Probits and Weights in Probit Analysis. Biometrika. 1948;35(1/2):191-201.

Grzybowski A, Tiboni M, Silva MAN, Chitolina RF, Passos M, Fontana JD. Pest Manag Sci. 2013;69:589-601.

Issaoui M, Delgado AM. Grading, Labeling and Standardization of Edible Oils. In: Ramadan MF. (eds.) Fruit Oils: Chemistry and Functionality. Springer Nature Switzerland AG; 2019. p. 9-52.

Jiang WG, Bryce RP, Horrobin DF. Essential fatty acids: molecular and cellular basis of their anti-cancer action and clinical implications. Crit Rev Oncol Hematol. 1998;27(3):179-209.

Lima LARS, Johann S, Cisalpino PS, Pimenta LPS, Boaventura MAD. In vitro antifungal activity of fatty acid methyl esters of the seeds of Annona cornifolia A. St.-Hil. (Annonaceae) against pathogenic fungus Paracoccidioides brasiliensis. J Braz Trop Med. 2011;44:777-780.

Lima LARS, Alves TMA, Zani CL, Pimenta LPS, Boaventura MA. Antioxidant and citotoxic potential of fatty acid methil esters from the seeds of Annona cornifolia A. ST.-Hil. (Annonaceae). Food Research International. 2012;48:873-875.

Luzia DMM, Jorge N. Soursop (Annona muricata L.) and sugar apple (Annona squamosa L.). Nutr Food Sci. 2012;42(6):434-441.

Luzia DMM, Jorge N. Bioactive substance contents and antioxidant capacity of the lipid fraction of Annona crassiflora Mart. seeds. Ind Crops Prod. 2013;42(1):231-235.

Meterissian SH, Forse RA, Steele GD, Thomas P. Effect of membrane free fatty acid alterations on the adhesion of human colorectal carcinoma cells to liver macrophages and extracellular matrix proteins. Cancer Lett. 1995;89(2):145-52.

Moon H-S, Batirel S, Mantzoros CS. Alpha linolenic acid and oleic acid additively down-regulate malignant potential and positively cross-regulate AMPK/S6 axis in OE19 and OE33 esophageal cancer cells. Metabolism. 2014;63(11):1447-1454.

MoralesCA, GonzalesRO, AragonR. Evaluaciondelaactividad larvicida de extractos polares y no polares de acetogeninas de Annona muricata sobre larvas de Aedes aegypti y Anopheles albimanus (Diptera: Culicidae). Rev Colomb Entomol. 2004;30(2):187-192.
National Institute of Standard and Technology, NIST/EPA/ NIH Mass Spectral Database, Standard Reference Database 1, National Institute of Standard and Technology, Gaithersburg, MD; 1992.

National Institute of Standard and Technology, NIST 98, Standard Reference Database 1, Standard Reference Data Program, National Institute od Standards and Technology, Gaithersburg, MD; 1998.

Paulo MQ, Barbosa-Filho JM, Lima EO, Maia RF, Barbosa RC, Kaplan MA. Antimicrobial activity of benzylisoquinoline alkaloids from Annona salzmanii A. DC. J. Ethnopharmacol. 1992; 36:39-41.

Pereira MCT, Nietsche S, Costa MR, Crane JH, Corsato CDA, Mizobutsi EH. Anonáceas: pinha, atemoia e graviola. Inf Agropecuário. 2011;32(264):1-9.

Ramadan MF. Chemistry and Functionality of Fruit Oils: An Introduction. In: Ramadan MF. (eds.) Fruit Oils: Chemistry and Functionality. Springer Nature Switzerland AG; 2019. p. 3-8.

Rasmussen, S.A.; Jamieson, D.J.; Honein, M.A.; Petersen, L.R., Zika Virus and Birth Defects--Reviewing the Evidence for Causality. New Engl J Med. 2016;374(20): 1981-1987.

Reyes-Trejo B, Guerra-Ramírez D, Zuleta-Prada H, CuevasSánchez JA, Reyes L, Reyes-Chumacero A, et al. Annona diversifolia seed oil as a promising non-edible feedstock for biodiesel production. Ind Crops Prod. 2014;52:400-404.

Ribeiro SS, De Jesus AM, Dos Anjos CS, Da Silva TB, Santos ADC, De Jesus JR, et al. Evaluation of the cytotoxic activity of some Brazilian medicinal plants. Planta Med. 2012;78(14):160-606.

São José AR, Pires MDM, Freitas ALGE de, Ribeiro DP, Perez LAA. Atualidades e perspectivas das Anonáceas no mundo. Rev Bras Frutic. 2014;36(spe1):86-93.

Santos SRL, Silva VB, Melo MA, Barbosa JDF, Santos RLC, Sousa DP, Cavalcanti SCH. Toxic effects on and structuretoxicity relationships of phenylpropanoids, terpenes, and related compounds in Aedes aegypti larvae. Vector Borne Zoonotic Dis. 2010;10:1049-1054.

Sassaki GL, Souza LM, Serrato RV, Cipriani TR, Gorin PAJ, Iacomini M. Application of acetate derivatives for gas chromatography-mass spectrometry: Novel approaches on carbohydrates, lipids and amino acids analysis. J Chromatogr A. 2008;1208(1-2):215-222.

Senthil R, Silambarasan R. Annona: A new biodiesel for diesel engine: A comparative experimental investigation. J Energy Inst. 2015;88(4):459-469. 
Chemical composition, larvicidal and cytotoxic activity of Annona salzmannii (Annonaceae) seed oil

Silva LE, Reis RA, Moura EA, Amaral W, Sousa Jr PT. Plantas do Gênero Xylopia: Composição Química e Potencial Farmacológico. Rev Bras Pl Med. 2015;17(4):814-826.

Sobrinho RB. Potencial de Exploração de Anonaceaes no Nordeste do Brasil. Fortaleza: Embrapa Agroindústria Tropical. 2010. 27 p.

Songa, EA, Okonkwo JO. Recent approaches to improving selectivity and sensitivity of enzyme-based biosensors for organophosphorus pesticides: A review. Talanta. 2016;155:289-304.

Soto-Guzman A, Villegas-Comonfort S, Cortes-Reynosa P, Perez Salazar E. Role of arachidonic acid metabolism in Stat5 activation induced by oleic acid in MDA-MB-231 breast cancer cells. Prostaglandins. Leukot Essent Fat Acids. 2013;88(3):243-249.

Suffness M, Pezzuto JM. Assays related to cancer drug discovery. In: Hostettmann K, editor. Methods in plant biochemistry: assays for bioactivity. Academic Press: London; 1990. p. 71-133.

Wang Z, Liu D, Zhang Q, Wang J, Zhan J, Xian X, et al. Palmitic acid affects proliferation and differentiation of neural stem cells in vitro. J Neurosci Res. 2014;92(5):574-586.

WHO. Pesticides and their Application for the Control of Vectors and Pests of Public Health Importance. World Health Organization, Geneva. 2006.

WHO/CDS/NTD/WHOPES/GCDPP/2006.1, Geneva. WHO (2015) Dengue and Severe Dengue. Fact sheet 117, Geneva.

Zajdel A, Wilczok A, Tarkowski M. Toxic effects of n-3 polyunsaturated fatty acids in human lung A549 cells. Toxicol Vitr. 2015;30(1):486-491.

Received for publication on $18^{\text {th }}$ June 2018 Accepted for publication on $20^{\text {th }}$ November 2019 